\title{
СПОСІБ РОЗРАХУНКУ ЛОКАЛІЗАЦІЇ ДЖЕРЕЛА ШУМІВ У ТРИВИМІРНОМУ ПРОСТОРІ ДЛЯ ДІАГНОСТИКИ ПНЕВМОНІЇ У ДІТЕЙ МОЛОДШОГО ВІКУ
}

\author{
А. Є. Апікова, Д. О. Федотов, В. А. Клименко \\ Харківський національний університет радіоелектроніки \\ Харківський національний медичний університет ${ }^{1}$
}

\begin{abstract}
У статті теоретично обґрунтоване використання принципу GPS-технології для діагностики пневмоній. Матриця датчиків, розташована на грудній клітці пацієнта, $є$ неактивною складовою системи, на відміну від супутників, що використовуються у GPS. Спосіб реалізується за допомогою рівнянь GPS-навігації, у яких замінюються змінні. Розраховуючи час приходу респіраторного аускультативного шуму до кожного з датчиків матриці отримують координати джерела запального процесу у тривимірному просторі. За отриманими координатами роблять висновок про глибину та місце положення запального процесу (пневмонії) у легенях пацієнта.
\end{abstract}

Ключові слова: бронхофонографрія, пневмонія, GPS-технологія.

\section{СПОСОБ РАСЧЁТА ЛОКАЛИЗАЦИИ ШУМОВ В ТРЁХМЕРНОМ ПРОСТРАНСТВЕ ДЛЯ ДИАГНОСТИКИ ПНЕВМОНИЙ У ДЕТЕЙ МЛАДШЕГО BO3PACTA}

\author{
А. Е. Апикова, Д. А. Федотов, В. А. Клименко \\ Харьковский национальный университет радиоэлектроники \\ Харьковский национальный медицинский университет ${ }^{1}$
}

\begin{abstract}
В статье теоретически обосновано использование принципа GPS-технологии для диагностики пневмоний. Матрица датчиков, располагающаяся на грудной клетке пациента, является неактивной составляющей системы, в отличие от спутников, которые использован ы в GPS. Способ реализуется при помощи уравнений GPS-навигации, в которых производится замена переменных. Рассчитывая время прихода респираторного аускультативного шума к каждому из датчиков матрицы получают координаты источника воспалительного процесса в трёхмерном пространстве. По полученным координатам делают вывод о глубине и месте положения воспалительного процесса (пневмонии) в лёгких пациента.
\end{abstract}

Ключевые слова: бронхофонография, пневмония, GPS-технология.

\section{METHOD FOR DETERMINING OF SOUNDS LOCALIZATION IN THREE- DIMENSIONAL SPACE FOR DIAGNOSIS OF PNEUMONIA IN YOUNG CHILDREN}

\author{
A. E. Apikova, D. A. Fedotov, V. A. Klymenko ${ }^{1}$ \\ Kharkiv National University of Radioeiectronics \\ Kharkiv National Medical University ${ }^{1}$
}

\begin{abstract}
The theoretical justification for using of the GPS-technology principle for the pneumonia diagnosis was made in the article. The sensor's matrix is located on a patient's chest and it's an inactive system's component unlike satellites used in GPS. The method is implemented using the GPS-navigation formula with some variables replacements. For determining of the coordinates of the sounds source in the three-dimensional space it's necessary to calculate time from sound's source to each sensor of matrix. According to the obtained coordinates the conclusion about the depth and location of the inflammation process (pneumonia) in the patient lungs can be made.
\end{abstract}

Key words: bronchophonography, pneumonia, GPS-technology.

Вступ. Пневмонія - гостре інфекційне захворювання, найчастіше бактеріальної етіології, що харак- теризується вогнищевим або частковим ураженням респіраторних відділів легень, наявністю внутріш- 
ньоальвеолярної ексудації, вираженою різною мірою лихоманкою та інтоксикацією [1].

Патологія органів дихання займає одне з перших місць у структурі захворюваності дитячого населення, наприклад, пневмонія є головною інфекційною причиною смертності дітей (15\% усіх випадків смерті серед дітей до 5 років ) у всьому світі. В 2013 році від пневмонії померло 935 тисяч дітей у віці до 5 років [2].

При прослуховуванні хворого (аускультації) лікар намагається з'ясувати місцезнаходження джерела патологічних шумів та за характером звуку виявляє вид патології. Від характеру аускультативних звуків (крепітація, сухі чи вологі хрипи, шум тертя плеври) залежить клінічний діагноз [3]. У деяких випадках виникають нечіткі та погано чутні звуки, що змушує лікаря сумніватися при встановленні діагнозу. Крім того, у дітей молодшого віку процес аускультації має певні труднощі та обмеження: маленька дитина часто плаче при дослідженні, не може виконувати команди лікаря про контрольоване дихання; у цьому віковому періоді не застосовуються об'єктивні методи дослідження респіраторної системи, такі як спірометрія та пікфлоуметрія. 3 причин, що вказані вище, трапляються випадки помилкових діагнозів [4].

Мета роботи: автоматизація процесу аускультації при умові використання спеціальної техніки. Це дозволить прослуховувати легені пацієнта, не зважаючи на внутрішні та зовнішні шуми, що не несуть інформації про патологічні процеси в дихальних шляхах, записувати звукові феномени та відстежувати прогрес лікування, використовувати дані для телемедицини та навчання майбутніх лікарів-пульмонологів.

Матеріали та методи дослідження. При записі сигналу, що отримується з датчиків, є резон відстежувати його за часовою складовою, звертаючи увагу на час приходу до кожного 3 датчиків корисної складової сигналу. Завдяки цьому можна розрахувати місце положення джерела шуму в об'ємі, у даному випадку у грудній клітці пацієнта. А саме: для виявлення місця джерела шуму слід вимірювати моменти часу прийому сигналу від джерела. Формулювання схоже на принцип роботи GPS-навігації. Для з'ясування координат GPS-технології використовується розрахунок за чотирма рівняннями: «відстань дорівнює добутку швидкості світла на різність моментів прийому сигналу споживачем та моменту його синхронного випромінювання від супутників» [5].

$$
\left|x-\alpha_{j}\right|=c\left(t_{j}-\tau\right)
$$

де $\alpha_{j}$ - місце положення $j$ - го супутника, $t_{j}$ - момент часу прийому сигналу від $i-$-го супутника за годинником споживача, $\tau$ невідомий момент часу синхронного випромінення сигналу усіма супутниками за годинником споживача, $\boldsymbol{c}$ - швидкість світла, $x$ - невідоме тривимірне положення споживача.

Але за умов живого організму рівняння в оригінальному вигляді не можуть бути використані, оскільки швидкість проходження звуку у змінному середовищі (біологічному об'єкті) відмінна від швидкості світла у вакуумі (для ідеальних умов). Крім того, замість супутників, що знаходяться на орбіті Землі, використовують акустичні датчики, які накладаються на шкіру пацієнта навколо грудної клітки. Для нових умов слід замінити швидкість світла на швидкість поширення звуку в щільному рідкому середовищі, наприклад воді, тому що тіло містить багато рідини. Як наслідок, замінимо у початковому рівнянні складові на необхідні для нових умов та отримаємо рівняння, за допомогою яких можна розрахувати місце розташування джерела шумів в об'ємі грудної клітки, взявши до уваги іiі розміри.

Для розрахунку місця розташування запального процесу 5 К необхідно прив'язати об'єкт дослідження 8 і матрицю 3 датчиків 4 Д. до системи координат. В даному випадку доцільно використовувати циліндричну систему 2 координат, оскільки матриця 3 датчиків 4 Д. розташовується на площині, яка симетрично описує циліндр навколо осі 2. Об'єкт дослідження 8 «вписаний» в створюючу циліндр площину з розташованою на ній матрицею 3 датчиків 4 Д Припустимо, що точка 5 К є джерелом сигналу 7. Тоді координати точки 5 К будуть описані таким чином: К(к', ф, т). У цьому виразі к' є проекцією на площину ХУ точки 5 К. Тому відстань 2 К дорівнює відстані Ок'. ф - кут між віссю $\mathrm{X}$ та відрізком Ок'. Отже, т дорівнює аплікат точки 5 К (рис. 1).

3 вищесказаного випливає висновок, що точку К можна прив'язати до Декартової системи координат таким чином:

$$
\left\{\begin{array}{c}
x=k^{\star} \cos \varphi \\
y=k^{`} \sin \varphi \\
z=z^{`}
\end{array}\right.
$$

Розглянемо матрицю датчиків, розташовану на циліндричній площині навколо осі 2. Розташування в просторі кожного датчика опишемо так: в циліндричній системі координат кожний датчик з матриці датчиків позначимо Д 


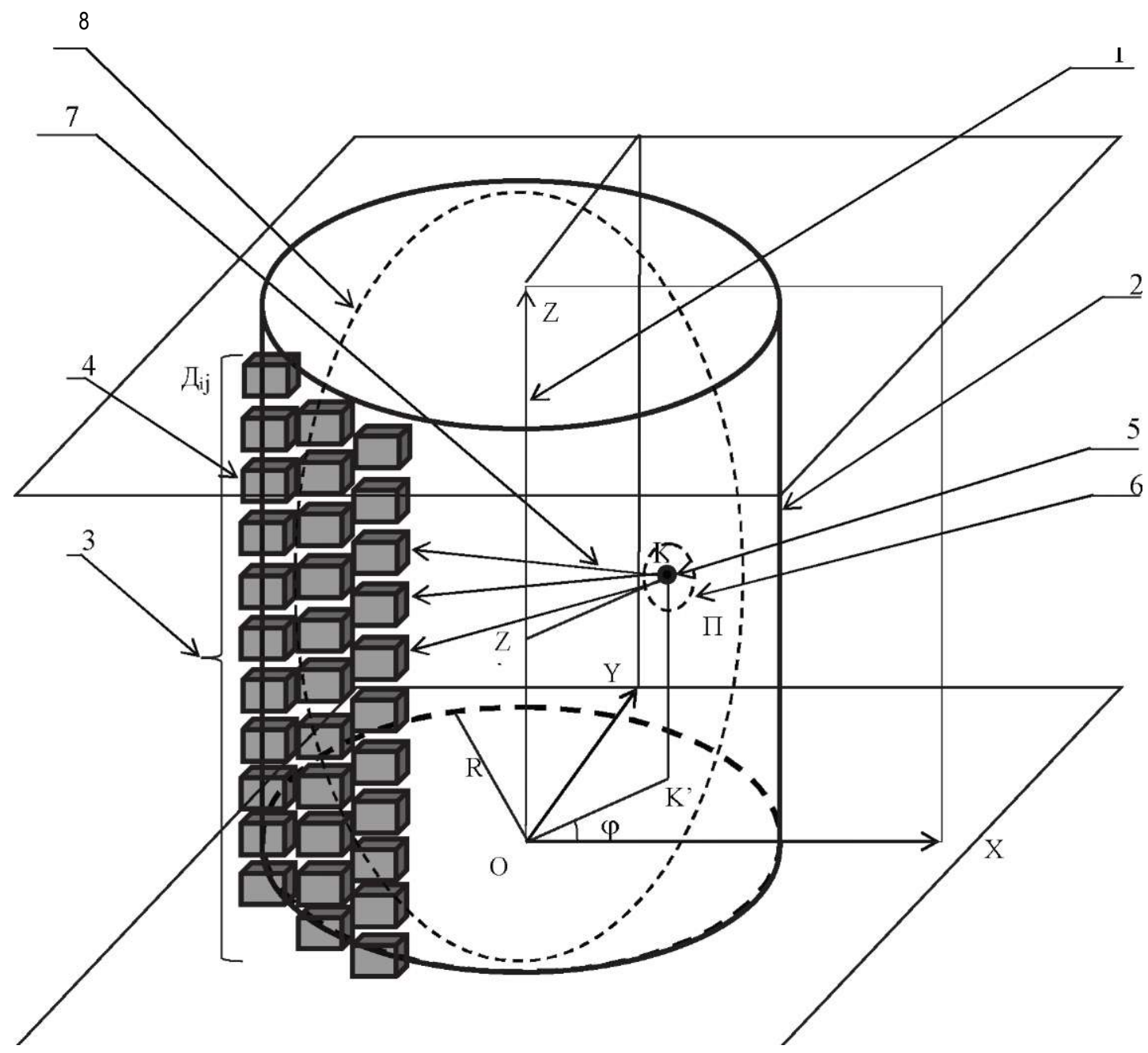

Puc. 1. Положення матриці датчиків у системі координат та розташування біологічного об' єкта 3 джерелом шумів.

таку координату Д(к', ф, z), отже, перевівши координати $з$ циліндричної системи в Декартову, отримаємо:

$$
\left\{\begin{array}{c}
x=R \cos \varphi \\
y=R \sin \varphi \\
z=z_{i j}
\end{array}\right.
$$

де Я - радіус циліндра, що описаний навколо осі Z.

В оригінальному вигляді рівняння GPS-навігації не можуть бути використані для розрахунку координат джерела запального процесу, викликаного пневмонією (надалі джерело). Перетворивши рівняння
Датчики Д що знаходяться у просторі і прив'язані до Декартової системи координат, утворюють матрицю такого вигляду:

$$
N=\left(\begin{array}{llll}
Д_{11} & Д_{12} & \cdots & Д_{1 j} \\
Д_{21} & Д_{22} & \cdots & Д_{2 j} \\
\vdots & \vdots & & \vdots \\
Д_{i 1} & Д_{i 2} & \cdots & Д_{i j}
\end{array}\right)
$$

(1), 3 координат кінця вектора віднімаємо координати початку вектора i, підставивши нові змінні, отримаємо ліву частину рівняння:

$$
\left|д_{i j}-x\right|=K д_{i j}\left(R \cos \varphi-K^{\prime} \cos \varphi ; R \sin \varphi-K^{\prime} \sin \varphi ; z_{i j}-z^{\prime}\right)
$$


Ліва частина перетвореного рівняння GPS дорівнює координатам вектора КД. Отже, довжина вектора КД розраховується таким чином:

$$
K Д_{i j}=\sqrt{\left(R \cos \varphi-K^{\prime} \cos \varphi\right)^{2}+\left(R \sin \varphi-K^{\prime} \sin \varphi\right)^{2}+\left(z_{i j}-z^{\prime}\right)^{2}}
$$

Далі, замінивши швидкість світла на швидкість поширення звуку в воді, отримаємо:
Дане рівняння показує відстань, яку проходить звук від джерела до кожного датчика Д. за певний час в біологічному об'єкті.

Підставивши усі змінні отримаємо:

$$
\sqrt{\left(R \cos \varphi-K^{\prime} \cos \varphi\right)^{2}+\left(R \sin \varphi-K^{\prime} \sin \varphi\right)^{2}+\left(z_{i j}-z^{\prime}\right)^{2}}=v\left(\tau-t_{i j}\right)
$$

Обидві частини рівняння описують довжину відстані, яку проходить звук від джерела до кожного датчика Д.. В отриманому рівнянні невідомими будуть координати джерела К $\left(\kappa^{\prime}, \phi\right.$, e) i момент часу випромінювання шуму джерелом К т. Для визначення координат і моменту часу випромінювання слід вирішити систему рівнянь:

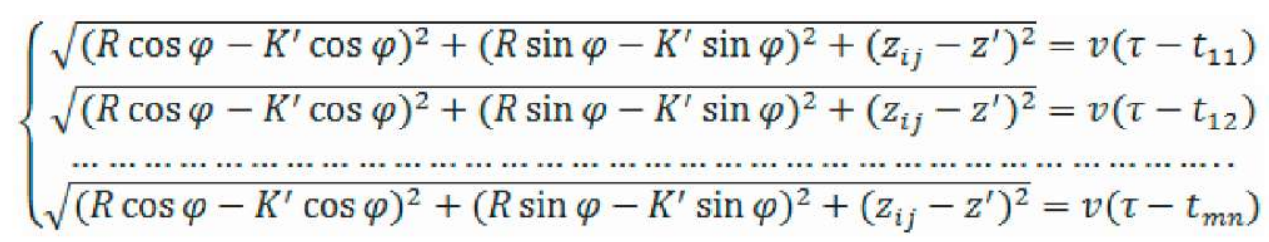

Отже, підставивши змінні в оригінальному рівнянні GPS-навігації і вирішивши систему рівнянь (9), отримаємо координати джерела К в розглянутому біологічному об'єкті.

Висновки. Такий спосіб для розрахунку джерел шумів пневмоній при реалізації має суттєві переваги характеристик, а саме: можливість виявляти місце положення запальних процесів, викликаних пневмонією, в легенях пацієнта, не використовуючи складних та небезпечних методів діагностики; можливість

\section{Література}

1. Яковлев В. П. Рациональная антимикробная фармакотерапия : Руководство / В. П. Яковлев, С. В. Яковлев. М. : Литерра, 2003. - 1004 с.

2. Пневмония. Информационный бюллетень № 331, ноябрь 2014 г. [Электронный ресурс]. - Режим доступу: http:// www.who.int/mediacentre/ factsheets/fs3 31/ru/.

3. Справочник педиатра / [авт. кол. В. Г. Арсентьев, А. О. Булыгина, Н. В. Гончар и др.]. - 3-е изд. ; под ред. проф. Н. П. Шабалова. - СПб. : Питер, 2014. - 736 с.: ил. - (Серия «Спутник врача»): 412 - 418 с. визначати характер патології за специфікою шумів і джерелом розташування їх у дихальній системі; підвищену точність діагнозу вже на першому огляді лікаря-пульмонолога за рахунок отримання даних про характер та глибину залягання запального процесу, викликаного пневмонією. За допомогою описаного способу можна проводити розрахунок координат місця розташування джерел запального процесу, викликаних пневмоніями, відносно датчиків.

4. Восканян А. Г. Пневмония. Особенности течения и лечение больных астмой [Электронный ресурс] / А. Г. Восканян, А. А. Восканян // Современные проблемы науки и образования. - 2007. - № 6, Ч. 2. - С. 20-32. - Режим доступу: http://www.science-education.ru/24.

5. Шебшаевич В. С. Сетевые спутниковые радионавигационные системы / [В. С. Шебшаевич, П. П. Дмитриев, Н. В. Иванцев и др.] / под ред. В. С. Шебшаевича. - 2-е изд., перераб. и доп. - М. : Радио и связь, 1993. - 408 с. : ил. 